\title{
The effect of enzymatic pretreatment and $c / n$ ratio to biogas production from rice husk waste during solid state anaerobic digestion (SS-AD)
}

\author{
Syafrudin ${ }^{1, *}$, Winardi Dwi Nugraha ${ }^{1}$, Hashfi Hawali Abdul Matin ${ }^{1}$, and Budiyono ${ }^{2}$ \\ ${ }^{1}$ Department of Environmental Engineering, Diponegoro University, 50275 Semarang, Indonesia \\ ${ }^{2}$ Department of Chemical Engineering, Diponegoro University, 50275 Semarang, Indonesia
}

\begin{abstract}
Rice husk is one of agricultural waste generated from the mill is potential to be converted to biogas. Otherwise, biogas production facing problem due to the high lignin content. This research is objected to study the effect of enzymatic pretreatment and $\mathrm{C} / \mathrm{N}$ ratio to biogas production from rice husk by solid state anaerobic digestion (SS-AD). The laboratory scale-anaerobic digestions was used in this work. It is operated in batch system and with room temperature. Total solid (TS) was set $21 \%$. Enzymatic pretreatment was conducted using lignase enzyme. Carbon to Nitrogen $(\mathrm{C} / \mathrm{N})$ ratio was varied from 20,25 , 30 , and 35. The $\mathrm{C} / \mathrm{N}$ ratio is varied by adding some quantity of technical urea to the substrate. Biogas formed was measured using water displacement method in every two days. The result showed that enzymatic pretreatment could increase biogas production from 30 to $55 \%$. The highest biogas production was obtained at $\mathrm{C} / \mathrm{N}$ ratio 35 . Specific biogas production on $\mathrm{C} / \mathrm{N}$ ratio of $20,25,30$, and 35 were respectively $12.0,12.6,13.5$ and $18.2 \mathrm{ml} / \mathrm{gr}$ TS. The volumetric loading resulted by SS-AD was higher than liquid anaerobic digestion (L-AD). The further research need to conduct for optimization the enzyme concentration and $\mathrm{C} / \mathrm{N}$ ratio.
\end{abstract}

\section{Introduction}

Agricultural activities are very important not only from an economic view point but also produces waste as a sustainable energy such as biogas [11] Availability of abundant lignocellulosic raw materials in the world makes lignocellulose become high demand raw materials for biofuel production [24]. Lignocellulosic material contained by crop residue is difficult to be degraded by anaerobic bacteria. Lignocellulosic often contain lignin with high concentrations.

Pretreatment on lignocellulosic raw materials also aims to facilitate the conversion of biopolymer contained in the cellulose. Pretreatment performed may increase total yield of methane [14]. Pretreatment can be performed pretreatment of physics, chemistry and biology [23]. Pretreatment of physics can be performed by size reduction to reduce the particle size and the degree of crystallinity of cellulose. The process of size reduction can increase total hydrolysis yield as much as $5-25 \%$ and reduces digestion time of approximately $23-$ $59 \%$ [17].

The processes of anaerobic digestion are classified into two based on the content of total solids (TS) that is liquid anaerobic digestion (L-AD) and solid-state anaerobic digestion (SS-AD) [22]. Liquid anaerobic digestion (L-AD) used on the total solid content of between 0.5 to $15 \%$, while the total solid content of $>15 \%$ using a solid-state process of anaerobic digestion (SS-AD) [27]. Lignocellulosic biomass feedstock such as rice husk is suitable to be treated using the SS-AD due to the concentration of total solid on lignocellulosic biomass $>15 \%$ and has a low moisture content $[3,20]$. In addition, problems that occur in the L-AD-like substrate floats, fat and fiber stratification can not be found on the SS-AD [26]. [3] The volume of methane production from lignocellulosic biomass generated in the SS-AD is 2-7 times greater than with L-AD. [12] The similar result also expressed, that biogas production volume increased by $278-357 \%$ in SS-AD as compared to LAD. Another advantage SS-AD include: reactor volume is smaller, needs less water, does not require stirring, no precipitation occurs in the bottom of the reactor, the residue of the $\mathrm{SS}-\mathrm{AD}$ can be used as fertilizer because it has a low water content so it is more easily handled than waste of L-AD $(16,19]$.

Several studies of biogas production from lignocellulosic biomass using methods SS-AD had been conducted. [19] which conducts research biogas production from raw materials corncob yielding the largest biogas in the ratio F/I 2.43 and TS content of $22 \%$. [21] Research with the raw materials of food waste and grass with SS-AD method. [13] Research on biogas with rice straw raw materials have also been carried out, which aims to determine the effect of type of inoculum to the production of biogas, but in these studies using meode $\mathrm{L}-\mathrm{AD}$ and did not evaluate the

\footnotetext{
* Corresponding author : udin_syaf@yahoo.com
} 
effect of the ratio F/I, TS content and physical pretreatment effect on the production of biogas.

[3] conducted a study of SS-AD (TS 18-19\%) of corn cobs, straw, wheat, reeds and leaves. The raw material is dried at $40{ }^{\circ} \mathrm{C}$ for 48 hours until the moisture content of $10 \%$, then milled $5 \mathrm{~mm}$. The mixture was put into the reactor $1 \mathrm{~L}$ and incubated at $37{ }^{\circ} \mathrm{C}$ for 30 days. Biogas volume was measured 2-3 days. The highest biogas generated at $131.8 \mathrm{~L} / \mathrm{kgVS}$ with raw materials corncob. [27] Research SS-AD (TS $22 \%$ ) of corn cobs and the expired dog food. The content of dog food on the feedstock was $0 \%, 10 \%$, $25 \%, 50 \%$ and $100 \%$. The highest methane yield was $304.4 \mathrm{~L} / \mathrm{kgVS}$ on the ratio F/I 2 and $50 \%$ of $\operatorname{dog}$ food and $50 \%$ of corn cobs. The ratio F/I 4 with a mixture of $25 \%$ of dog food derived methane yield $171.5 \mathrm{~L} / \mathrm{kg} \mathrm{VS}$. The ratio F/I 6, yield of methane is $5 \mathrm{~L} / \mathrm{kgVS}$ with a mixture of $0 \%$ and $10 \%$ of dog food. SS-AD study was also conducted with the raw materials of sawdust [1]. Sawdust is collected washed with water, then added $0.2 \% \mathrm{H}_{2} \mathrm{SO}_{4}(\mathrm{w} / \mathrm{w})$ and heated at $140{ }^{\circ} \mathrm{C}$ for 45 minutes. The ratio of sawdust with cow dung 1:1.5. The study was conducted for 23 days. The cumulative volume of biogas generated at $1010 \mathrm{~mL}$.All of previous studies have been conducted, no SS-AD method used for processing rice husks into biogas. Nitrogen needs also are important for the SS-AD because of lignocellulosic biomass has high carbon content, but low nitrogen content. Therefore, this study will focus on the effect of pretreatment and $\mathrm{C} / \mathrm{N}$ ratio of the biogas production methods SS-AD.

\section{Materials and methods}

A series laboratory test of $600 \mathrm{ml}$ biodigester was operated during this research. The main experiment apparatus consists of biodigester and biogas measurement. Biodigester were made from polyethylene bottle plugged with tightly rubber plug and was equipped with valve for biogas measurement. Biogas formed was measured by 'liquid displacement method' as also has been used byseveral researchers before [7-10]. The schematic diagram of experimental laboratory set up as shown in Figure 1. Total solid (TS) was set $21 \%$. Enzymatic pretreatment was conducted using lignase enzyme. Carbon to Nitrogen ratio $(\mathrm{C} / \mathrm{N}$ ratio) was varied from 20, 25, 30, and 35 . Implementation of the research started with the process of making organic rice husk waste (biowaste), then conducting an examination of the total composition of solids and water content. Furthermore, the pretreatment process consists of the addition of $\mathrm{NaOH}$ and addition of enzyme. After that, the calculation and determination of the variation of $\mathrm{C} / \mathrm{N}$ ratio and the preparation of anaerobic batch reactor were conducted. Subsequently, the substrate is mixed with the inoculum and technical urea to adjust variations in $\mathrm{C} / \mathrm{N}$ ratio. Samples were prepared can be inserted into the reactor, sealed in order to obtain anaerobic condition, and ready for operation. During the treatment process takes place, volume of biogas produced were observed in interval of 2 (two) days. The observation was terminated after no more biogas formed.

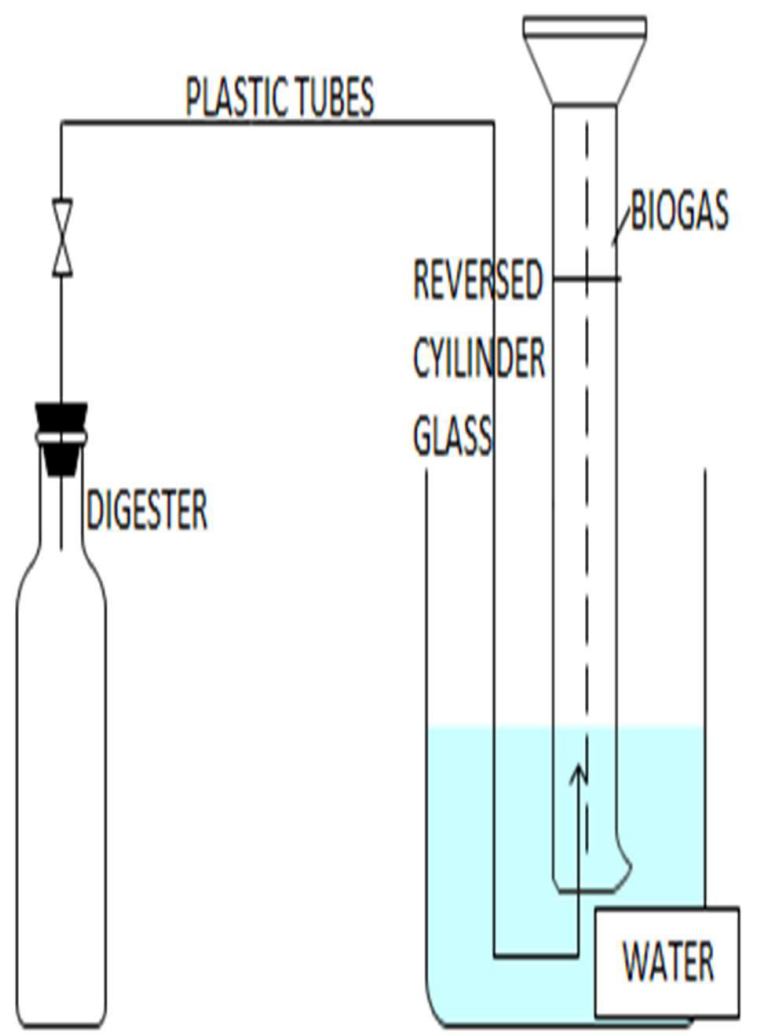

Fig. 1. Schematic diagram of series laboratory batch assessment of SS-AD

\section{Results and discussion}

\subsection{The influence of pretreatment to biogas production using SS-AD}

This phase of the research aims to determine the effect of pretreatment on production of biogas with SSAD. Effect of Pretreatment on biogas production was observed in this study with the addition of enzyme as much as $5 \%$ volume of the solution for all the variables, the addition of $\mathrm{NaOH}$ as much as $3 \%$ of the volume of the solution. Biogas volume measurement results during the 60-day trial is shown as a SS-AD biogas yield is calculated from the daily biogas volume divided by the content of TS on rice husk [18]. The cumulative biogas yield per unit TS and presented in Figure 2 to 6 .

Yield biogas showed that the ratio of $\mathrm{C} / \mathrm{N} 20$, pretreatment with the addition of enzymes significantly affect the production of biogas compared to pretreatment without using enzymes, can be seen in Figure 2. It can be seen that the total yield of biogas in the variable by using enzymes are higher, namely 11.9 $\mathrm{ml} / \mathrm{grTS}$ and for variables without the addition of enzymes obtained biogas yield of $10.25 \mathrm{ml} / \mathrm{grTS}$. 


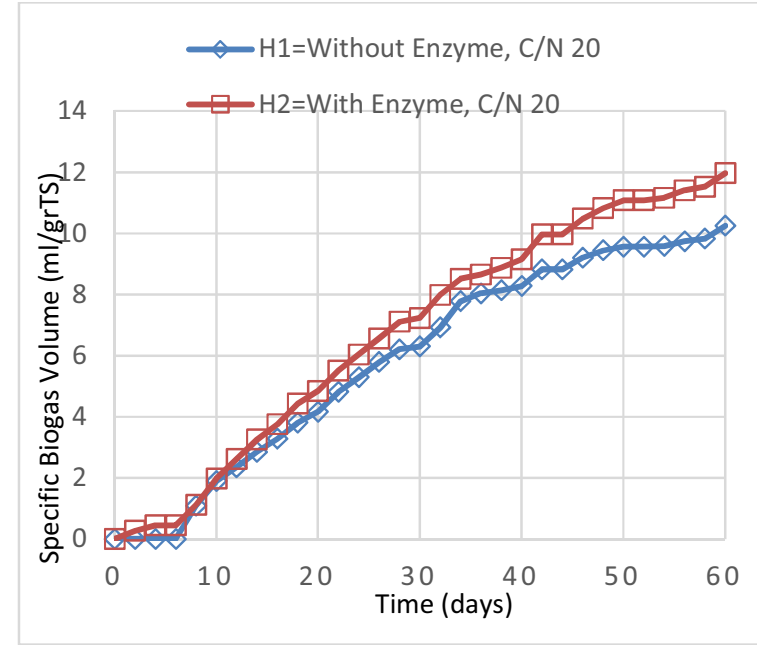

Fig. 2. The influence of enzymatic treatment to biogas yield at $\mathrm{C} / \mathrm{N}$ ratio 20

Yield biogas showed that the ratio of $\mathrm{C} / \mathrm{N} 25$, pretreatment with the addition of enzymes significantly affect the production of biogas compared to pretreatment without using enzymes, can be seen in Figure 3. In the $\mathrm{C} / \mathrm{N}$ ratio 25 that the data obtained for a total yield of biogas with the addition of enzymes at $12.6 \mathrm{ml} / \mathrm{grTS}$ and for variables without the addition of enzymes obtained biogas yield of $12.0 \mathrm{ml} / \mathrm{grTS}$.

[14] Pretreatment on lignocellulosic raw materials able to facilitate the conversion of biopolymer contained in the cellulose. Pretreatment performed will increase total yield of methane. Pretreatment can be performed pretreatment of physics, chemistry and biology [23]. Pretreatment of physics can be performed by size reduction to reduce the particle size and the degree of crystallinity of cellulose.

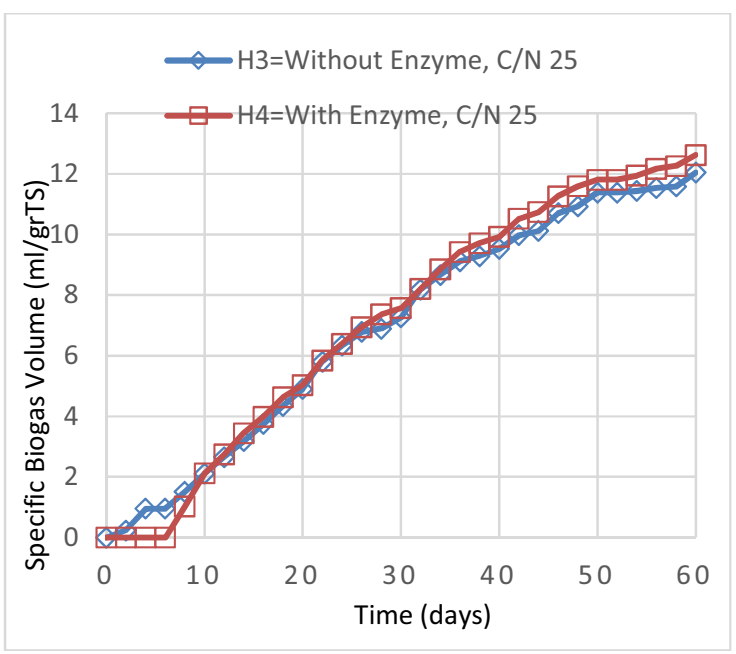

Fig. 3. The influence of enzymatic treatment to biogas yield at $\mathrm{C} / \mathrm{N}$ ratio 25

In Figure 4 yield biogas showed that the ratio of $\mathrm{C} / \mathrm{N} 30$, pretreatment with the addition of enzymes have higher biogas yield than without pretreatment using enzymes but not too significant, can be seen in Figure 4. The data obtained for a total yield of biogas with the addition of an enzyme of $13.9 \mathrm{ml} / \mathrm{grTS}$ and for variables without the addition of enzymes obtained biogas yield of $13.5 \mathrm{ml} / \mathrm{grTS}$.

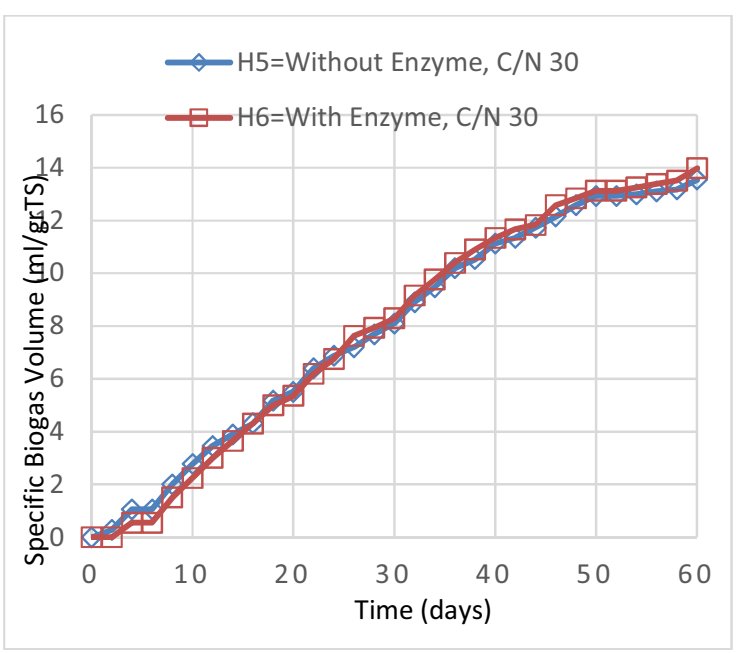

Fig. 4. The influence of enzymatic treatment to biogas yield at $\mathrm{C} / \mathrm{N}$ ratio of 30

In Figure 5 biogas yield indicates that the $\mathrm{C} / \mathrm{N}$ ratio of 35 , with the addition of enzyme pretreatment significantly affect the production of biogas compared to pretreatment without using enzymes, can be seen in Figure 5. It can be seen that the total yield of biogas in the variable by using enzymes greater, namely 18.2 $\mathrm{ml} / \mathrm{grTS}$ and for variables without the addition of enzymes obtained biogas yield of $13.5 \mathrm{ml} / \mathrm{grTS}$.

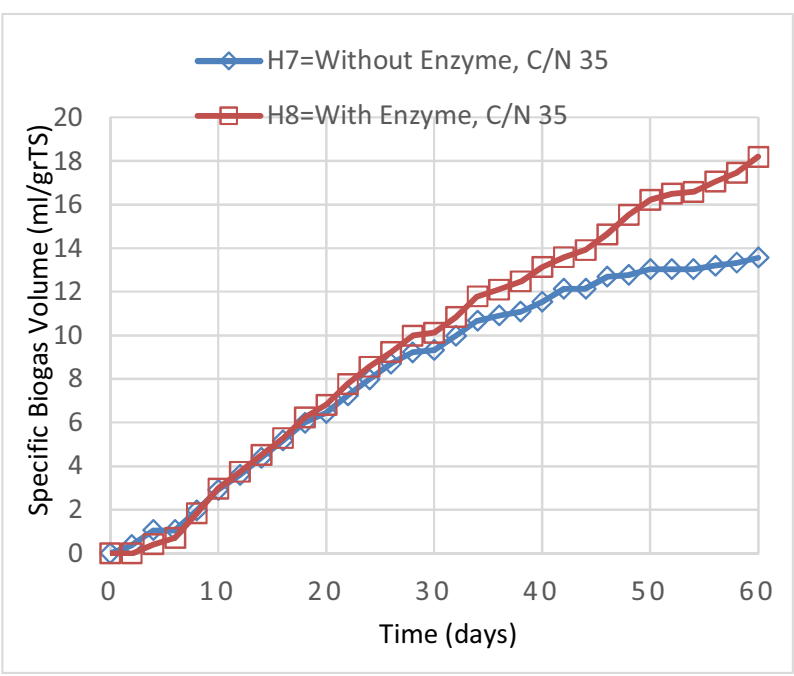

Fig. 5. The influence of enzymatic treatment to biogas yield at $\mathrm{C} / \mathrm{N}$ ratio of 35

In Figure 6 under conditions of $\mathrm{C} / \mathrm{N}$ ratio 25 indicated that the pretreatment with the addition of $\mathrm{NaOH}$ significant effect on the production of biogas compared with no use of $\mathrm{NaOH}$ pretreatment. It can be seen that the total yield of biogas in the variable by using $\mathrm{NaOH}$ greater, namely $12.6 \mathrm{ml} / \mathrm{grTS}$ and for variables without the addition of $\mathrm{NaOH}$ obtained biogas yield of $11.0 \mathrm{ml} / \mathrm{grTS}$. 


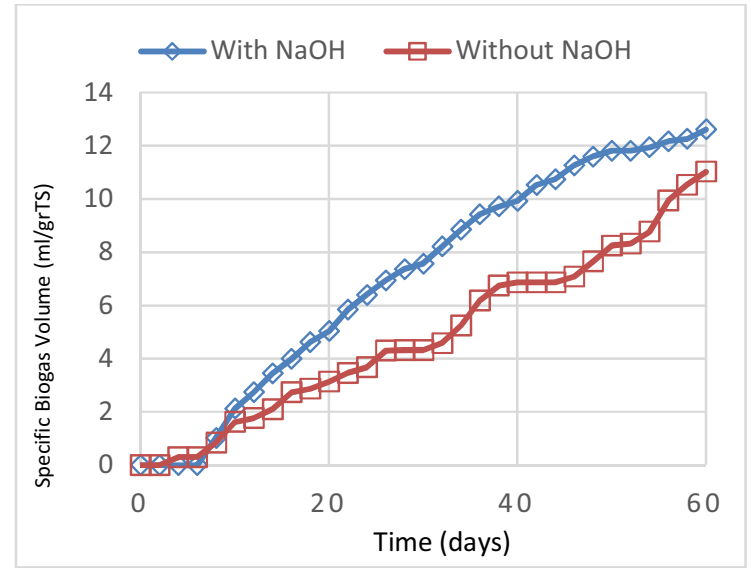

Fig. 6. The influence of $\mathrm{NaOH}$ pretreatment to biogas yield, $\mathrm{C} / \mathrm{N}$ ratio of 25

\subsection{The influence of $\mathrm{C} / \mathrm{N}$ ratio to biogas production during SS-AD}

In this study, the effect of $\mathrm{C} / \mathrm{N}$ ratio of the biogas production was observed with a variety of $\mathrm{C} / \mathrm{N}$ ratio of $20,25,30$ and 35. Data are presented as the volume of cumulative biogas yield during the 60-day trial of SS$\mathrm{AD}$, as shown in Figure 7.

Figure 7 shows the cumulative volume of biogas per unit TS on rice husk with the addition of enzymes. In the rice husk $\mathrm{C} / \mathrm{N} 20$, the total volume of biogas that is equal to $12.0 \mathrm{ml} / \mathrm{grTS}$. In the rice husk $\mathrm{C} / \mathrm{N} 25$ biogas cumulative volume of $12.6 \mathrm{ml} / \mathrm{grTS}$. In the rice husk $\mathrm{C} / \mathrm{N} 30$ biogas cumulative volume of 13.5 $\mathrm{ml} / \mathrm{grTS}$, and for rice husk $\mathrm{C} / \mathrm{N} 35$ volume cumulative biogas up to the 60th day, in the amount of 18.2 $\mathrm{ml} /$ grTS which is the highest biogas yield, because it is based on some information obtained, so that the growth of anaerobic bacteria optimum, optimum required of $\mathrm{C} / \mathrm{N}$ ratio ranges from $20: 1$ to $35: 1$ and a bit wet environmental conditions.

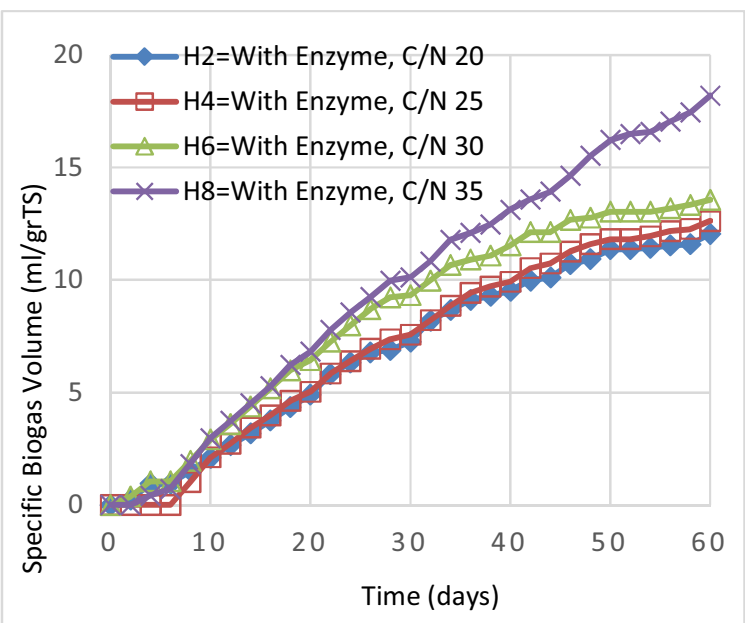

Fig. 7. The influence of $\mathrm{C} / \mathrm{N}$ ratio to biogas production with enzymatic treatment

In Figure 8 can be seen the cumulative volume of biogas per unit TS on rice husk without the addition of enzymes. In the rice husk $\mathrm{C} / \mathrm{N} 20$ total biogas yield is $10.25 \mathrm{ml} / \mathrm{grTS}$. In the rice husk $\mathrm{C} / \mathrm{N} 25$ biogas cumulative volume of $12.0 \mathrm{ml} / \mathrm{gr}$ TS. In the rice husk $\mathrm{C} / \mathrm{N} 30$ biogas cumulative volume of $13.54 \mathrm{ml} / \mathrm{grTS}$, and the rice husks $\mathrm{C} / \mathrm{N} 35$ cumulative volume biogas up to the 60th day, which amounted to $13.56 \mathrm{ml} / \mathrm{grTS}$ which is the highest biogas yield. [2] During 104 days of observation, C/N ratio optimum is around 20-30 because it is reflected from the soluble concentration of COD with the highest value of removal efficiency in $68.21 \%$ for reactor variation $2(\mathrm{C} / \mathrm{N}$ ratio 30$)$ and volatile content with the highest value of removal efficiency also in $19.86 \%$ for variation $3(\mathrm{C} / \mathrm{N}$ ratio $20)$. Variation of $\mathrm{C} / \mathrm{N}$ ratio respectively affects the degradation process in each reactor. [15] This research results is also higher that obtained that after 52 days observation, specific biogas production was 10.78 $\mathrm{ml} /$ grTS with the substrate of rice husk and cow dung. Sample A (50 wt \% cow dung, 50 wt \% rice husk) showed a cumulative biogas production of $161.5 \mathrm{ml}$ at the end of the $38^{\text {th }}$ day of the experiment after which there was no further production. The production from sample B (25 wt \% cow dung, $75 \mathrm{wt} \%$ rice husk) was not significant, while there was no production from sample $\mathrm{C}(0 \mathrm{wt} \%$ cow dung, $100 \mathrm{wt} \%$ rice husk $)$.

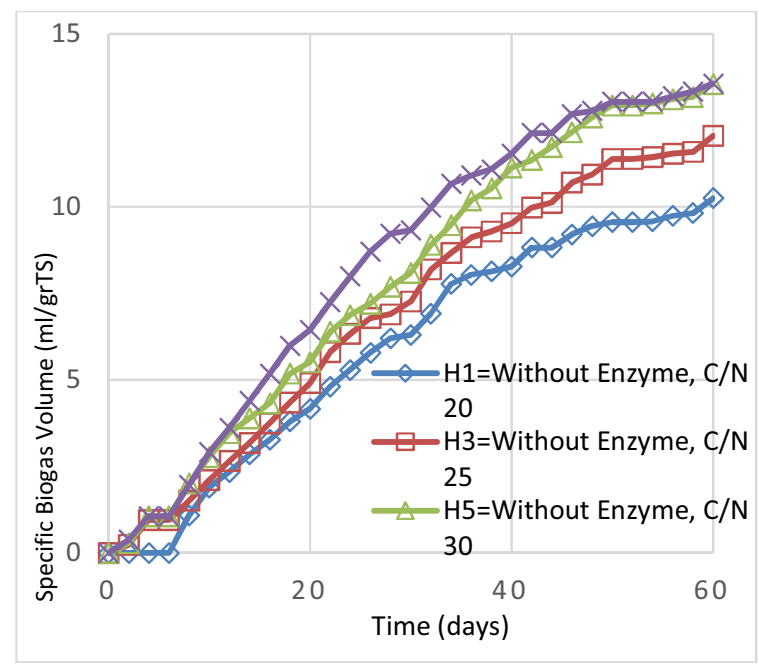

Fig. 8. The influence of $\mathrm{C} / \mathrm{N}$ ratio to biogas production without enzymatic treatment

\section{Conclusions}

Rice husk is one of agricultural waste generated from rice mill which have a high potential to be processed into biogas. Enzymatic pretreatment could increase biogas production varied from 30 to $55 \%$. The highest biogas production was obtained at $\mathrm{C} / \mathrm{N}$ ratio 35. Specific biogas production on $\mathrm{C} / \mathrm{N}$ ratio of 20 , 25,30 , and 35 were $12.0,12.6,13.5$ and $18.2 \mathrm{ml} / \mathrm{grTS}$, respectively. SS-AD has volumetric loading of biogas production higher than in generally liquid anaerobic digestion (L-AD). The further research need to be studied was optimization of enzyme concentration and $\mathrm{C} / \mathrm{N}$ ratio. 
We highly thank and appreciate to Diponegoro University through Research Professorship Program (RPP) 2016 due to the funding of this research.

\section{References}

1. Akwaka, J.C., Kukwa, D.T., Mwekave, S.S. International Journal of Science and Technology, 3(4), 222-228 (2014)

2. Arifiantari, P.N., Handajani, M., and Sembiring, T.https://jujubandung.wordpress.com/2012/06/10/ pengaruh-rasio-cn-terhadap-degradasi-materialorganik-dalam-sampah-pasar-secara-anaerob-2/ (2012)

3. Brown, D., Li, Y. Bioresource Technology, 127, 275-280 (2013)

4. Brown, D., Shi, J., Li, Y. Bioresource Technology, 124, 379-386 (2012)

5. Budiyono, Widiasa I.N., Johari S., Sunarso. World Academy of Science, Engineering and Technology, 37:983-988 (2010)

6. Budiyono, I N. Widiasa, S. Johari, and Sunarso. International Journal of Engineering and Technology, 1(3):109-116, ISSN : 0975-4024 (2009)

7. Budiyono, I. Syaichurrozi, S. Sumardiono. World Applied Sciences Journal 26 (11): 1464-1472. (2013)

8. Budiyono, Iqbal S., Siswo S. Research Journal of Applied Sciences, Engineering and Technology 7(3):2798-2805. (2014)

9. Budiyono, I. Syaichurrozi and S. Sumardiono. International Journal of Engineering, Vol. 27(2):177-184. (2014)

10. Budiyono, S. Sumardiono and D. Tri Mardiani. International Journal of Engineering, Vol. 28(2): 921-928 (2015)

11. Chandra, R., Takeuchi, H., Hasegawa, T., \& Kumar, R.. J Appl Energy, 94:129-40. (2012)
12. Chen, X., Yan, W., Sheng, K., Sanati, M. Bioresource Technology, 154, 215-221. (2014)

13. Gu, Y., Chen, X., Liu, Z., Zhou, X., Zhang, Y. Bioresource Technology, 158, 149-155 (2014)

14. Hendriks, A.T.W.M., Zeeman, G. Bioresource Technology, 100, 10-18 (2009)

15. Iyagba, E.T., Mangibo, I.A. and Mohammad, Y.S. Scientific Research and Essay, 4 (9), pp. 861-866 (2009)

16. Karthikeyan, O.P., Visvanathan, C. Rev Environ Sci Biotechnol, 12, 257-284 (2013)

17. Krátký, L., Jirout, T., Nalezenec, J. Lab-scale Acta Polytechnica, 52(3), 54-59 (2012)

18. Li, Y., Park, S.Y., Zhu, J. Renewable and Sustainable Energy Reviews, 15(1), 821-826 (2011)

19. Li, Y., Zhu, J., Wan, C., Park, S.Y. American Society of Agricultural and Biological Engineers, 54(4), 1415-1421 (2011)

20. Liew, L.N., Shi, J., Li, Y. Biomass and Bioenergy, 46, 125-132 (2012)

21. Liu, G., Zhang, R., El-mashad, H.M., Dong, R. Bioresource Technology, 100(21), 5103-5108 2009)

22. Mirmohamadsadeghi, S., Karimi, K., Zamani, A., Amiri, H., Horváth, I.S. BioMed Research International, 1-6 (2014)

23. Schimpf, U., Hanreich, A., Mähnert, P., Unmack, T., Junne, S., Renpenning, J., Lopez-ulibarri, R. Journal of Sustainable Energy \& Environment, 4, 53-60 (2013)

24. Teghammar, A. Thesis : Chalmers University of Technology (2013)

25. Xu, F., Li, Y. Bioresource Technology, 118, 219$226(2012)$

26. Xu, F., Shi, J., Lv, W., Yu, Z., Li, Y. Waste Management, 33(1), 26-32 (2014)

27. Zhu, J., Zheng, Y., Xu, F., Li, Y. Bioresource Technology, 154, 240-247 (2014) 